\title{
SÍMBOLOS DE DESCENSO E INTIMIDAD EN EL ARTE INFANTIL
}

\author{
María Belén León-Río \\ belenleon@us.es
}

\section{RESUMEN}

El arte pondría en marcha la imaginación del creador plástico, sacando a la luz de la consciencia una serie de imágenes simbólicas relacionadas con el descenso que suelen ir acompañadas por símbolos de intimidad como protectores en este viaje al interior de nuestro ser esencial. Estas producciones artísticas se crearían a partir de la vivencia primordial del artista cuya naturaleza se expresaría mediante figuras mitológicas que funcionarían de manera inconsciente y que nos ayudarían a descubrir otras partes de nuestra psique donde operarían unas determinadas teologías, lo que demostraría que estas representaciones simbólicas tendrían concomitancias con las manifestaciones de la actividad espiritual humana estudiadas en la investigación etnológica. En este artículo veremos cuáles son estos arquetipos surgidos de lo más hondo de la psique por medio de la actividad artística infantil, comprobándose cómo estas imágenes tendrían una gran influencia en nuestra vida ya que constituirían símbolos de transformación que armonizarían nuestra consciencia.

Palabras Clave: arquetipo, consciencia, inconsciente, descenso, intimidad.

\author{
SYMBOLS OF DESCENT AND INTIMACY \\ IN CHILDREN'S ART
}

\begin{abstract}
Art would set in motion the imagination of the plastic creator, bringing to light from consciousness a series of symbolic images related to the descent that are usually accompanied by symbols of intimacy as protectors on this journey into our essential being. These artistic productions would be created from the primordial experience of the artist whose nature would be expressed through mythological figures that would function unconsciously and that would help us discover other parts of our psyche where certain theologies would operate, which would demonstrate that these symbolic representations would have concomitances with the manifestations of human spiritual activity studied in ethnological research. In this article we will see which are these archetypes that emerged from the depths of the psyche through children's artistic activity, proving how these images would have a great influence on our life since they would constitute symbols of transformation that would harmonize our consciousness.
\end{abstract}

KEYWORDs: archetype, consciousness, unconscious, descent, intimacy. 


\section{INTRODUCCIÓN}

C.G. Jung se pregunta cómo se forman las fantasías, diciendo cómo los poetas y los artistas nos dirían mucho acerca de ellas mientras que la ciencia no habría explicado suficientemente este fenómeno de aventura del cual nacería la obra creativa. Para este autor los poetas y los pensadores tendrían una influencia educativa sobre su sociedad actual y la posteridad: «... su influencia consiste en decir más alto y más claro lo que todos saben, y sólo en cuanto expresan ese "saber" inconsciente general causan un efecto educativo o seductor ${ }^{1}$. El artista a medida que avanza comienza a tener una visión más amplia del mundo, convirtiéndose en un gran precursor del cambio que la sociedad occidental está experimentando desde el siglo Xx. Nuestra edad de la razón tiene los días contados iniciándose actualmente una nueva edad subjetiva, donde la acción y el desarrollo de una consciencia creativa generaría consecuencias y experiencias para la humanidad en este sentido, pues el individuo creativo sería más consciente de no quedarse bloqueado demasiado tiempo en la verdad parcial de un sistema establecido y en un orden temporal que consideramos erróneamente como eterno. El factor subjetivo exigiría toda la dignidad de un factor determinante del mundo, que en ningún tiempo y lugar puede ser excluido:

Es otra ley del mundo, y quien se basa en ella se basa en tanta seguridad, en tanta duración y validez como quien invoca el objeto. Pero, así como el objeto y los datos objetivos en modo alguno continúan siendo los mismos, por cuanto están sometidos tanto a la caducidad como a la casualidad, también el factor subjetivo se halla sometido a la mutabilidad y a la casualidad individual. Y con ello, también su valor meramente relativo ${ }^{2}$.

Según C.G. Jung en la representación reproducida pictóricamente donde el autor ignora conscientemente el surgimiento de sus formas «todos los procesos y efectos soterrados reproducidos pictóricamente son simbólicos, es decir, que aluden a un modo aproximado y de la mejor manera posible a un sentido que en un primer momento es desconocido ${ }^{3}$. El arte sería de naturaleza inconsciente, imponiéndose sin la colaboración de nuestra parte consciente a la que incluso llega a combatir, además de elegir "obstinadamente su forma y efecto»", este acontecimiento sería de carácter suprapersonal y rebasaría «el alcance del entendimiento consciente en la misma medida en que la consciencia del autor se aleja del desarrollo de su obra ${ }^{5}$. Jung en su libro titulado Liber Novus de 1914 y 1930 desarrolla una investigación sobre los símbolos donde busca paralelismos en la imaginaria, concluyendo que podía

${ }^{1}$ Carl Gustav Jung. Tipos psicológicos (Barcelona: Edhasa, 1994), 233-234.

2 Ibidem, 446.

${ }_{3}$ Carl Gustav Jung. Sobre el fenómeno del espiritu en el arte y en la ciencia (Madrid: Trotta, 2007), 126.

4 Ibidem, 67.

5 Ibidem. 
existir algo similar al proceso de imaginación que pudiese encontrarse en todas las culturas, analizando así sus analogías y diferencias. Para ello aplicó el método de Kristine Mann en sus investigaciones personales, esta educadora y médica estadounidense había pintado una numerosa serie de mandalas que sirvieron de referente a Jung, señalando, sobre el proceso seguido por Mann, cómo se podían pintar obras "cuyo verdadero contenido no se sospechaba en absoluto. Mientras se pinta, el cuadro prácticamente se va desarrollando por sí solo y a menudo en sentido contrario a la intención consciente» ${ }^{6}$. Los procesos y efectos escondidos del inconsciente surgirían en la representación simbólica por medio de la fantasía donde aparecerían imágenes muchas de ellas relacionadas con el descenso como el propio Jung escribe:

El descenso a una era prehistórica pertenece desde el testimonio de Homero a la Nekyia. Fausto se vuelve hacia el mundo primitivo y loco del Blocksberg y a la Quimera de la Antigüedad. Picasso concita burdas formas terrenas de grotesco primitivismo y hace resurgir, deslumbrante, lo desalmado de la Antigüedad pompeyana bajo una luz fría de un modo que no podría superar un Giulio Romano 7 .

El arte sería un medio que presentaría la realidad visible de un modo diferente a cómo la percibimos, para ello el individuo creativo emplearía la intuición, función que estaría íntimamente unida a la creación del símbolo apareciendo desde edades muy tempranas. J. Piaget y B. Inhelder señalan cómo existiría en el niño un «simbolismo centrado sobre el yo» ${ }^{8}$ que se expresaría mediante el juego simbólico, este no sería solamente una "asimilación de lo real al yo, como el juego general, sino asimilación garantizada por un lenguaje simbólico (lo que la refuerza) construido por el yo y modificable de acuerdo con las necesidades»". V. Lowenfeld y W. Lambert han estudiado el arte infantil diciendo cómo el niño sobre los siete ańos desarrollaría el símbolo al que daría el nombre de "esquema», este símbolo puede repetirse «una y otra vez, siempre que no haya una experiencia intencionada que ocasione un cambio en este símbolo» ${ }^{10}$.

Estos esquemas son definidos por C.G. Jung como imágenes primordiales o arquetipos, constituyendo posibilidades de representación de imágenes primitivas provenientes de la imaginación del ser humano desde tiempos inmemoriales, esta herencia explicaría cómo "ciertos materiales y motivos legendarios se repitan una y otra vez en la misma forma a lo largo de todo el planeta ${ }^{\prime 1}$. Las figuras mitológicas serían residuos psíquicos derivados de las experiencias y vivencias de nuestros antepasados: "En cierta medida son los de infinitas vivencias de pareja índole. Describen millones de experiencias individuales promediadas y de este modo ofrecen

${ }^{6}$ Carl Gustav Jung. El libro rojo (Buenos Aires: El Hilo de Ariadna, 2019), 109.

7 Carl Gustav Jung. Sobre el fenómeno..., op. cit., 129.

${ }^{8}$ Jean Piaget y Inhelder Bärbel. Psicología del niño. (Madrid: Morata, 2015), 63.

9 Ibidem.

${ }^{10}$ Viktor Lowenfeld y William Lambert. Desarrollo de la capacidad intelectual y creativa (Madrid: Síntesis, 2008), 290.

${ }^{11}$ Carl Gustav Jung. Escritos sobre espiritualidady transcendencia (Madrid: Trotta, 2018), 30. 
una imagen de la vida psíquica dividida y proyectada en las numerosas figuras del patrimonio mitológico" ${ }^{12}$. La obra de arte presentaría una simbología capaz de penetrar profundamente en el espectador, ya que el símbolo sería «siempre un reproche constante a nuestra capacidad de comprensión y empatía»" ${ }^{13}$.

En nuestros estudios sobre arte infantil hemos encontrado multiplicidad de imágenes simbólicas de descenso e intimidad, constituyendo arquetipos que se repetían de manera uniforme en las expresiones plásticas de un grupo de siete niños de ambos sexos, cuyas edades estaban comprendidas entre los dos y los nueve años. Durante un periodo de diez años hicimos un seguimiento de sus expresiones artísticas donde se recopilaron más de ochocientos dibujos y gran variedad de trabajos realizados con diversos materiales, encontrándose en estas producciones un sinnúmero de símbolos destacando los de descenso e intimidad que los niños de edades más tempranas representaban gráficamente. Volviéndose a repetir de nuevo en los trabajos de niños más mayores, por lo que pudimos comprobar una línea de evolución en todas las etapas de la infancia. En el análisis de los resultados se pudo observar además diferencias de estilo entre los niños estudiados y ciertas preferencias por algunos símbolos que surgían con más insistencia en un niño en concreto frente a otros del grupo; lo que nos llevó a concluir cómo estas imágenes tendrían que ver con una vía evolutiva personal apareciendo espotáneamente a medida que la conciencia se acrecentaba a lo largo de las distintas etapas de la infancia. La metodología que seguimos fue la de observar durante el periodo que duró la investigación el quehacer artístico de los niños, respetando su libertad creativa, su capacidad de aventura y descubrimiento, promoviendo la experimentación y creación independientes, además de propiciar la identificación emocional del nińo con su obra, motivándole de esta manera en la búsqueda de un lenguaje artístico acorde con sus propias necesidades expresivas.

Entre las representaciones simbólicas que fueron surgiendo en el transcurso de la investigación encontramos muchas de ellas relacionadas con esquemas geométricos donde aparecían cuadrados, rectángulos, triángulos y círculos que encarnaban en muchas ocasiones el centro psíquico del creador de esta imagen, ya que las figuras con una geometría cerrada cuadrada o rectangular como la ciudad, la fortaleza o la ciudadela tendrían que ver con «los temas de la defensa de la integridad interior $»^{14}$. El círculo o la esfera serían imágenes de un centro lleno de perfección, así «el espacio circular es más bien el del jardín del fruto del huevo, del vientre, y desplaza el acento simbólico a las voluptuosidades secretas de la intimidad $»^{15}$.

Según G. Durand nuestra imaginación elaboraría imágenes en relación con el descenso que necesitarían frente a la ascensión de una serie de precauciones que se traducirían en representaciones tales como corazas o escafandras, entre otras, ya

12 Carl Gustav Jung. Sobre el fenómeno..., op. cit., 73.

13 Ibidem, 69.

${ }_{14}$ Gilbert Durand. Las estructuras antropológicas de lo imaginario. Introducción a la arqueologia general (Madrid: Taurus, 1981), 236.

15 Ibidem, 236. 


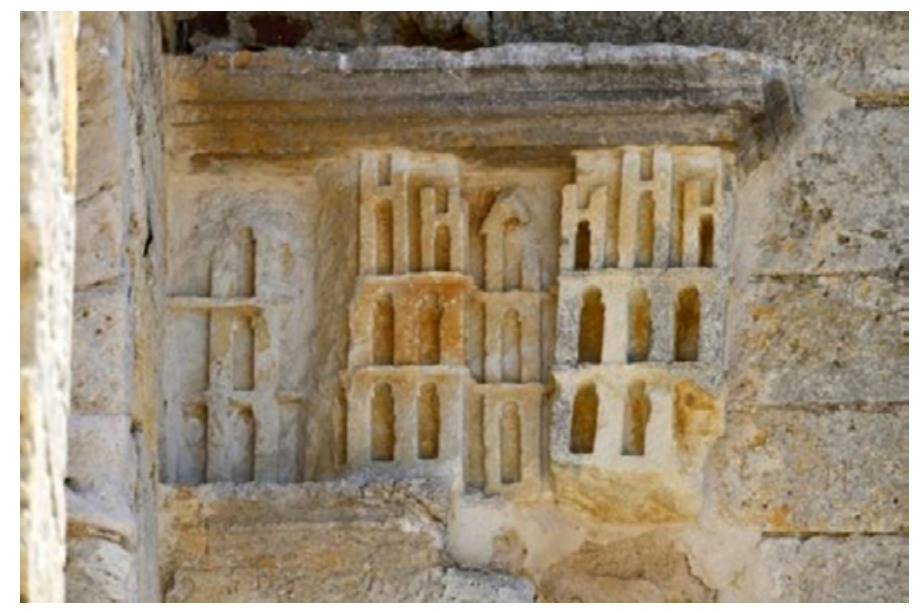

Figura 1. Capitel de Villalcázar de Sirga (Palencia), siglo XII.

que «el descenso corre el riesgo en todo instante de confundirse y de transformarse en caída. Debe ir constantemente acompañado, como para tranquilizarse, por los símbolos de intimidad ${ }^{16}$, de esta manera uno se protegería para penetrar en su centro más secreto como ocurre con el símbolo de la ciudad o el castillo que nos salvaguardarían del exterior. Para A. Jaffé la ciudad sería un símbolo sagrado que se vincularía con el mandala, constituyendo la proyección de una imagen arquetípica que surgiría del inconsciente hacía el exterior ya que la ciudad representaría «un cosmos ordenado, un lugar sagrado vinculado por su centro con el otro mundo. $\mathrm{Y}$ esa transformación armoniza con los sentimientos vitales y las necesidades del hombre religioso ${ }^{17}$. Algunas ciudades medievales se construyeron sobre planos de mandala inspirándose en la ciudad santa de Jerusalén que aparece en el Apocalipsis y que podemos ver en un capitel del templo fortaleza de Villalcázar de Sirga construida por los templarios en el siglo XII (fig. 1). El arte infantil reflejaría este simbolismo mediante ciudades encuadradas en esquemas geométricos como es el caso de este dibujo de un niño de siete años donde vemos la representación de una ciudad cuya línea compositiva sería un triángulo equilátero que simbolizaría la divinidad, la armonía y la proporción constituyendo un símbolo de totalidad psíquica que representarían la personalidad interior del niño (fig. 2).

16 Ibidem, 191.

17 Aniela Jaffé. «El simbolismo en las artes visuales» en El hombre y sus símbolos, C.G. Jung, (ed.), Col. Biblioteca Universal n. 3 (Barcelona: Caralt, 1997), 244. 


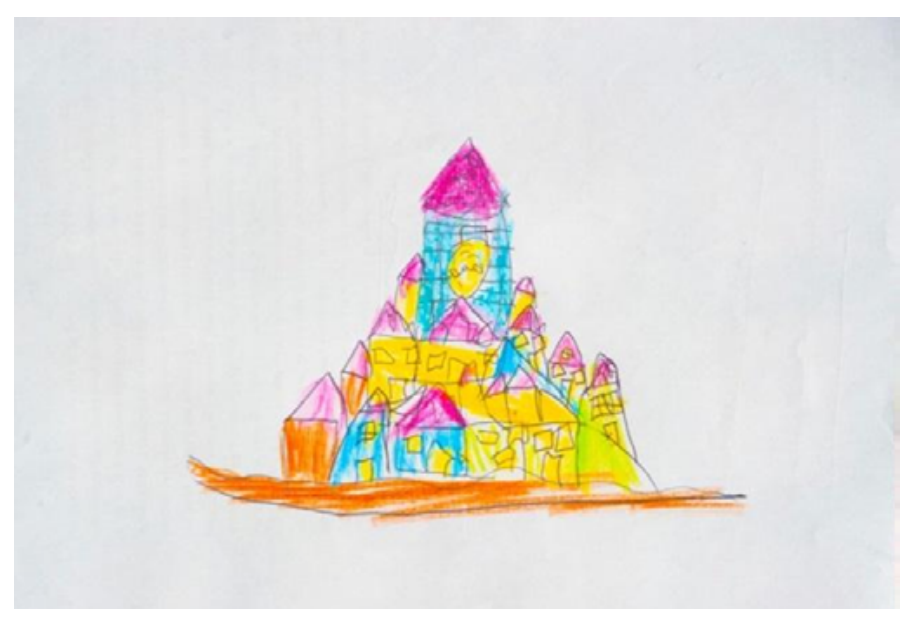

Figura 2. Dibujo de niño de 7 años.

D. Widlöcher señala cómo el dibujo infantil sería como un juego donde entraría en funcionamiento al mismo tiempo tanto la fantasía como la actividad gráfica seria, ya que los móviles del dibujo coincidirían al mismo tiempo con los del juego, por lo que este autor concluye que «la paradoja que hace descubrir la aparente antinomia entre seriedad y gratuidad del juego se aclara con la hipótesis de una actividad psíquica inconsciente» ${ }^{18}$. Para R. Kellogg el dibujo infantil tendría un contenido simbólico de carácter arquetípico como vemos en las configuraciones mandálicas de los niños y otras figuras geométricas desde las cuales se puede hacer un análisis del arte infantil. En 1954 esta psicóloga visitó a Jung, mostrándole sus investigaciones sobre la representación del mandala concluyendo cómo este símbolo constituiría «un eslabón fundamental en la evolución progresiva que conduce del trabajo abstracto a la pintura figurativa. El niño, de los mandalas accede a los soles y luego a las figuras humanas» ${ }^{19}$. Kellogg clasificó seis diagramas divididos mediante las figuras del rectángulo, el cuadrado, el óvalo, el círculo, el triángulo, la cruz o la X. Estas estructuras lineales se pueden unir formando "agregados» que serían «unidades de tres o más diagramas que el niño realiza entre los 2 y los 4 años. Su número es infinito y constituyen para la autora el grueso del arte infantil ${ }^{20}$. C.G. Jung señala cómo las figuras simbólicas se convertirían en un medio para poner en

${ }_{18}$ Daniel Widlöcher. Los dibujos de los niños. Bases para una interpretación psicológica (Barcelona: Herder, 1982), 129.

19 Antonio Machón Durango. Los dibujos de los niños. Génesis y naturaleza de la representación gráfica: un estudio evolutivo (Madrid: Cátedra, 2010), 61.

20 Ibidem, 60. 
comunicación nuestra realidad consciente con la inconsciente, siendo estos productos de la imaginación del ser humano, fantasías creadoras que estarían esperando a ser cristalizadas a un lenguaje conceptual:

Cada una de estas imágenes encierra un fragmento de psicología y de destino humano, una porción de dolor y de placer que se han experimentado indecibles veces en la cadena de nuestros ancestros y que, en términos generales, tuvo el mismo decurso. Es como un lecho de río profundamente enterrado en el alma, donde la vida, que antes se extendía a tientas por amplias, pero llanas, superficies, se adensa y se precipita repentinamente al alcanzar ese particular encadenamiento de circunstancias que siempre han colaborado a la concreción de la imagen primigenia ${ }^{21}$.

\section{EL MANDALA COMO SÍMBOLO DE INTIMIDAD EN EL ARTE INFANTIL}

C.G. Jung afirma cómo el gnosticismo y otros movimientos espirituales tendrían tendencia a tomar como reales las manifestaciones del inconsciente, de manera que creerían en ellas como una verdad definitiva, donde se ocultaría la esencia del mundo. Este hecho se produciría, porque en las exteriorizaciones espontáneas del inconsciente se manifestarían a través de una psique que no se identificaría con la consciencia en innumerables circunstancias: «Es ésta una actividad psíquica existente naturalmente, que ni es aprendida ni está sometida a la voluntad. La exteriorización de lo inconsciente es, en consecuencia, la manifestación de algo incognoscible que hay en el hombre ${ }^{22}$. Jung relaciona el inconsciente con la visión primordial del artista donde a través de sus arquetipos sería iniciado en el conocimiento secreto, como podemos ver en el arte prehistórico que ya tenía en sus comienzos un carácter eminentemente simbólico adoptando «las formas de un signo repleto de significado simbólico especial, de carácter mágico o sagrado» ${ }^{23}$.

C.G. Jung cree que nuestra alma sería capaz de producir imágenes que podían ser utilizadas artísticamente afirmando cómo había que inducir las fantasías mediante un entrenamiento que consistiría «en primer lugar en practicar sistemáticamente la suspensión de la atención crítica, con la que se produce un vacío de la consciencia $»^{24}$. Estas prácticas tenían para Jung un indudable carácter terapéutico, instruyendo a sus pacientes en los procesos de imaginación activa, mediante técnicas artísticas como el dibujo o la pintura para que los pacientes supieran conectar con su yo interior. En un seminario impartido en 1925 decía cómo su material empírico había salido de sus propios pacientes, pero también de sus experiencias con el

${ }^{21}$ Carl Gustav Jung. Sobre el fenómeno..., op. cit., 73.

22 Carl Gustav Jung. Psicología y simbólica del arquetipo. Col. Biblioteca de Psicología Profunda n. ${ }^{\circ} 29$ (Barcelona: Paidós, 1990), 122.

${ }^{23}$ Sigfried Giedion. El presente Eterno. Col. Alianza Forma n. ${ }^{\circ} 16$ (Madrid: Alianza, 1991), 34.

${ }^{24}$ Carl Gustav Jung, El libro..., op. cit., 78. 
inconsciente confesando que «la solución del problema la obtuve de lo interior, de mis observaciones de los procesos inconscientes $\aleph^{25}$.

En sus Libros negros comenzó a pintar sus primeros mandalas escribiendo lo siguiente sobre esta experiencia: «Este es el primer mandala que construí en el año 1916, completamente inconsciente de lo que significaba ${ }^{26}$ (como se citó en Jung 2019, 69). Estos mandalas fueron reproducidos más tarde en el Liber Novus, comprendiendo a través de ellos la idea del «sí-mismo» como una representación de la «naturaleza microscópica del alma» ${ }^{27}$. Para Jung el «sí-mismo» representaría el conjunto total de la psique incluyendo al yo, este último solo sería «un complejo entre otros complejos" ya que el yo, solo conocería una parte de nosotros mismos, no siendo idéntico a la totalidad de la psique incluida la parte inconsciente. Jung perdió la cuenta de los mandalas que dibujó por aquel entonces, explicando que en este proceso comprendió cómo «la idea de la superioridad del yo debía abandonarla por completo», experimentando así en sí mismo el proceso del inconsciente, diciendo sobre esta cuestión:

En primer lugar, tuve que dejarme arrastrar por esta corriente, sin saber adónde me conducía. Sólo cuando comencé a dibujar mandalas vi que todos los caminos que emprendía, y todos los pasos que daba, conducían de nuevo al único punto, concretamente al centro: Es la expresión de todos los caminos. Es el camino que lleva al centro, a la individuación ${ }^{28}$.

J.J. Jové llama la atención de cómo en las representaciones infantiles del periodo esquemático donde predominaría el gesto espontáneo en la elaboración del dibujo y se consolidaría la «intencionalidad figural» mediante la realización de trazos nítidamente perfilados, el niño tendría predilección por las configuraciones circulares en forma de sol teniendo esta imagen tal atractivo que todos los niños se dedicarían «durante un periodo de su evolución gráfica a dibujarlos con fruición sin que su reiteración parezca cansarles lo más mínimo»" ${ }^{29}$. El mandala como círculo cerrado constituiría una imagen de intimidad, un espacio sagrado que se asimilaría «al Paraíso en cuyo centro se asienta el Dios supremo, y en el que, una inversión ritual ha abolido el tiempo ${ }^{30}$, este espacio sagrado tendría "el poder de multiplicarse indefinidamente. La historia de las religiones insiste justamente en esta familiaridad de multiplicación de los "centros" y en la ubicuidad absoluta de lo sagrado"»1. Esta ubicuidad del centro tendría que ver con «la proliferación tanto de los Man-

25 Ibidem, 66.

26 Ibidem, 69.

27 Carl Gustav Jung. Recuerdos, sueños, pensamientos. Col. Biblioteca Breve (Barcelona: Seix Barral, 1996), 203.

${ }^{28}$ Ibidem, 204.

29 Juan José Jové. El desarrollo de la expresión gráfica. Col. Cuadernos de Educación n. ${ }^{\circ} 15$ (Barcelona: Horsori, 1994), 79.

${ }^{30}$ Gilbert Durand. Las estructuras..., op. cit., 235.

31 Ibidem, 237. 


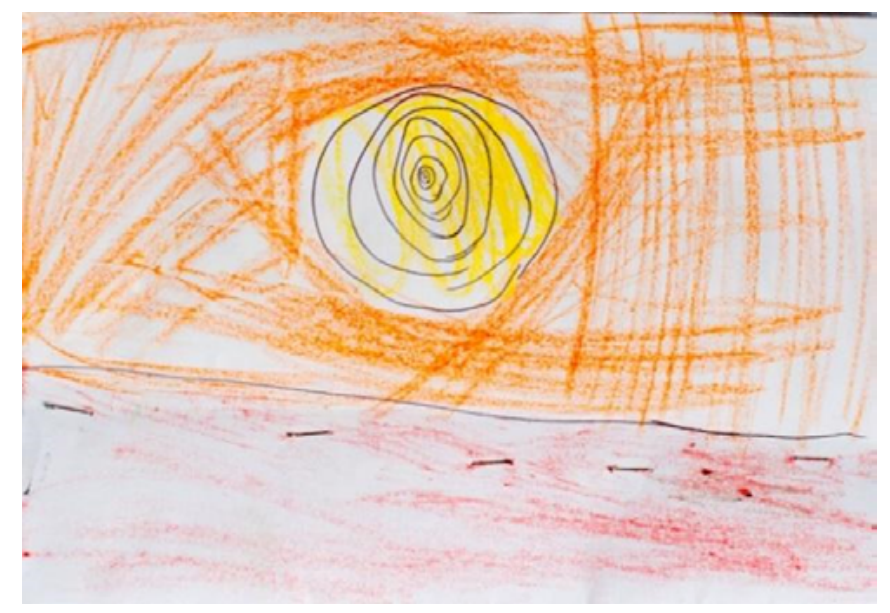

Figura 3. Dibujo de niño de 7 años.

dala como de los templos y de las iglesias consagradas a las mismas divinidades, que poseen los mismos vocablos y a veces las mismas reliquias ${ }^{32}$, esta multiplicación aparece igualmente en el arte de los niños, donde hemos encontrado símbolos concéntricos con una serie de anillos que parten de un centro que representarían su ser psíquico (fig. 3).

Según R. Lawlor la idea de la unidad incognoscible como comienzo ha sido la base de muchos sistemas fisiológicos y mitológicos. La unidad original, que se representaría por un círculo, se reafirmaría en el concepto de la «real idea», el pensamiento de Dios, que en la India llamaban el bindu o semilla, que se representaría por un punto geométrico. En los Comentarios del Shiva Sutra Vimarshini el punto constituiría el límite entre lo manifestado y lo no manifiesto, entre lo espacial y lo no espacial. El bidu correspondería a la «idea de semilla-sonido» del tantrismo. De tal manera que el Divino se transformaría en vibración sonora (nada), proliferando el universo que no sería distinto a sí mismo, que daría forma o expresión verbal a esta «autoidea». El universo surgiría así de la palabra, que sería una vibración o materialización del pensamiento divino que daría lugar al fraccionamiento de la unidad que sería su creación:

La palabra (saabda en sánscrito, el logos de los cristianos y los gnósticos), cuya naturaleza es pura vibración, representa la naturaleza esencial de todo cuanto existe. Las ondas vibratorias concéntricas se expanden hacia fuera desde innumerables centros, y sus superposiciones (esquemas de interferencia) forman nódulos de energía

32 Ibidem. 
atrapada que se convierten en los ígneos cuerpos rotatorios del firmamento. La real idea, el Purusha, el punto inaudible e invisible del sonido-idea permanece fijo e inmutable. Sus nombres, sin embargo, pueden investigarse a través de la geometría y los números. Ese sonido emitido, esa enunciación de la idea de Dios, es lo que los pitagóricos llamarían la música de las esferas ${ }^{33}$.

C.G. Jung compara la totalidad psíquica del ser humano con el atman bindu, cuya fenomenología define como existencia personal y cósmica, constituyendo el hombre más vasto e intemporal y que se correspondería a la idea del hombre primigenio, que sería completamente redondo y bisexual debido al hecho de que representaría una integración mutua de lo consciente y lo inconsciente, siendo "yo y no yo, subjetivo y objetivo, individual y colectivo ${ }^{34}$. Entre la consciencia y el inconsciente habría una especie de "relación» de indeterminación, porque sería imposible establecer una separación entre el observador y lo observado, ya que el primero modificaría al segundo por el acto mismo de observar, explicando que la exactitud de observación del inconsciente se lograría a costa de la exactitud de observación de la consciencia y así recíprocamente: "Así, el sí-mismo aparece en cualesquiera figuras, de las más altas hasta las más bajas, en la medida en que ellas sobrepasen el ámbito de la personalidad del yo con carácter de daimónion ${ }^{35}$. El «sí-mismo» trabajaría como una energía que apunta hacia una totalidad, donde el yo estaría subordinado al «símismo» e iría más allá de sus valores e ideas, pudiendo incluso ir contra ellas, pues el «sí-mismo» nos enfrentaría constantemente a un camino de cambio y reevaluación.

C.G. Jung confesaba como a través de los mandalas que esbozaba a diario "podía observar día a día las transformaciones psíquicas» ${ }^{36}$ señalando como el mandala tendría que ver con un proceso de "formación-transformación» de nuestra individualidad donde buscaríamos una integridad de nuestra personalidad, siendo el desarrollo psíquico la propia persona donde no existiría un desarrollo lineal, sino que solo existiría una "circunvalación del uno mismo»" El círculo o mandala sería el arquetipo de lo celestial, del cielo, de Dios y el alma, ya Platón representaba la psique con una esfera, lo redondo en la Edad Media correspondió a la piedra filosofal, la cual se asocia también a la idea del segundo Adán, ser de naturaleza pura y no corruptible. En la cosmogonía que expone Platón en el Timeo, aparece el universo en forma de esfera:

Él (el dios) le dio [al Uno Todo de los Todos] una figura [skhema] adecuada y semejante [syggenes]. Sería adecuado que quién ha de tener en él todas las cosas vivientes, tuviera la figura que capta en sí misma todas cuantas figuras hay. Por eso le

33 Robert Lawlor. Geometría Sagrada (Madrid: Debate, 1993), 22.

${ }^{34}$ Carl Gustav Jung. La psicología de la transferencia. Col. Biblioteca Profunda n. ${ }^{\circ} 6$ (Barcelona: Paidós, 1993), 131-132.

${ }^{35}$ Carl Gustav Jung, AION. Contribución a los simbolismos del si-mismo. Col. Biblioteca de Psicología Profunda n. ${ }^{\circ} 113$ (Barcelona: Paidós, 1995), 237.

36 Carl Gustav Jung. Recuerdos..., op. cit., 202.

37 Ibidem, 204. 
dio forma de esfera -desde el centro por doquier equidistando de los extremos- y lo torneó en forma de círculo - de todas las figuras la más acabada y la más completamente semejante respecto de ella misma- después de considerar que lo semejante es diez mil veces más hermoso que lo desemejante ${ }^{38}$.

Otras imágenes del centro serían el cofre y la caverna que se relacionarían con el simbolismo del corazón «bien como correspondencias o como sustituciones»" Este mismo significado sería encarnado por el vaso y el cáliz, arquetipo de soberanía y perfección que enlazaría con el corazón, este al igual que el santo Grial se pueden representar mediante un triángulo invertido como vemos en el antiguo Egipto, donde la vasija sería el hieroglifo del corazón, mientras que en la India el triángulo invertido sería «uno de los principales símbolos de la Shakti, elemento femenino del ser, al mismo tiempo que las aguas primordiales $»^{40}$. R. Lawlor dice cómo en la India la membrana o canal de nacimiento se simbolizaría mediante el triángulo al que designan la Madre, ya que es por este canal por el cual «todos los poderes transcendentes de la unidad y su división inicial en una polaridad deben pasar para entrar en el reino manifiesto de la superficie ${ }^{41}$. También en el pensamiento infantil aparece el problema del nacimiento que se caracterizaría según Piaget por la creencia de que el bebé sería preexistente al nacimiento, siendo una idea extendida en los niños que «los muertos se vuelven pequeños y renacen bajo la forma de bebés» ${ }^{42}$, de esta manera la gente se volvería nińo cuando se aproximan a su vejez o los muertos volverían a renacer como se puede comprobar en esta frase de un niño llamado Klein que dice: «Entonces yo también me moriré: tú (mamá) también... y luego volveremos los dos» ${ }^{43}$. Según G. Durand la muerte sería un retroceso hacia una segunda infancia como se puede ver en "los nińos de cuatro a siete años que reinventan el mito de Politico y creen que a partir de una edad avanzada los viejos se vuelven progresivamente nińos» ${ }^{44}$. El retorno a la madre tendría que ver con el reposo y la intimidad como vemos con frecuencia en sociedades que «asimilan el reino de los muertos con aquel del que vienen los niños como Chicomoztoc, "lugar de las siete grutas del antiguo México"» ${ }^{45}$. Para C.G. Jung la hendidura de la tierra sería un símbolo de la madre al igual que la cavidad, el útero, las entrañas, la cámara, la copa, el grial, el vaso, el recipiente o la caverna lugar donde se produciría una revitalización. El templo cristiano sería un sepulcro-catacumba o relicario sepulcral, «tabernáculo donde descansan las santas especies, pero también matriz, regazo donde renace Dios. Muchas iglesias, así como, muchos templos de los cultos con misterios de la

469.

38 Jean Chevalier y Alain Gheerbrant. Diccionario de los simbolos (Barcelona: Heder, 1999),

39 Juan Cirlot. Diccionario de simbolos (Barcelona: Labor, 1969), 153.

40 Jean Chevalier y Alain Gheerbrant, loc. cit., 344.

${ }^{41}$ Robert Lawlor. Geometría..., op. cit., 12.

42 Jean Piaget. La representación del mundo en el niño (Madrid: Morata, 2008), 307.

43 Ibidem

${ }^{44}$ Gilbert Durand. Las estructuras..., op. cit., 225.

45 Ibidem, 224. 


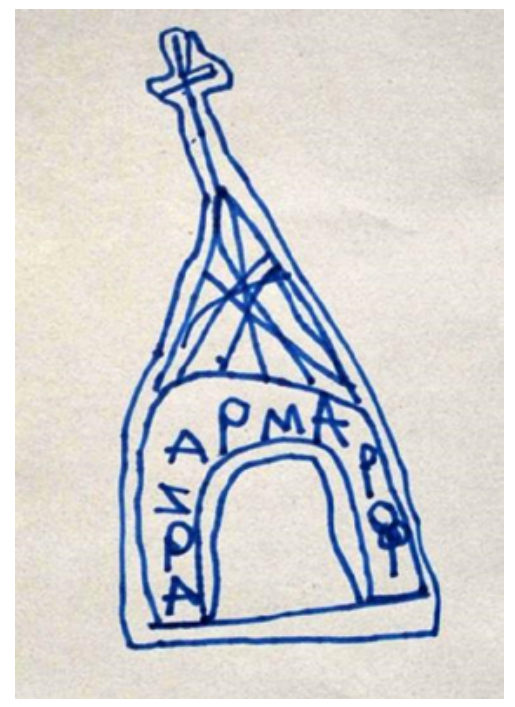

Figura 4. Dibujo de niño de 4 años.

antigüedad pagana, están erigidos cerca o sobre cavernas o grietas: San Clemente en Roma y Lourdes prosiguen la tradición de Delfos, Hierópolis y Kos» ${ }^{46}$. J. Campbell llama la atención al devoto que antes de entrar en el templo se despojaría de su ropaje secular al igual que la serpiente mudaría su piel: «Una vez dentro puede decirse que ha muerto al tiempo y que ha retornado al Útero Cósmico, al Ombligo del Mundo, al Paraíso Terrenal» ${ }^{47}$. Los niños representan estos espacios sagrados como una casa-relicario que tendría que ver con esta imagen de renovación e intimidad como vemos en este dibujo de un niño de cuatro años (fig. 4). En este caso el niño no habría realizado una copia fiel de la realidad, sino que la representaría según G.H. Luquet mediante un «modelo interno» que intervendría en el desarrollo del dibujo y en su significación, así «cuando el niño tiene que dibujar un objeto por primera vez le es necesario crear en su alma el modelo interno» ${ }^{48}$ (Luquet 1998, 62).

El mito de la pérdida del Grial tendría que ver con la pérdida de la vinculación con nuestro interior tanto a nivel religioso como de «las formas degradadas (psicológicas) del misterio, de cualquier "fuente de felicidad". Por ello, ese abandono del recuerdo trae consigo la pérdida del estado primordial o paradisiaco, la muerte

\section{Ibidem, 230.}

${ }^{47}$ Joseph Cambell. «El vientre de la ballena», en C. Zweig y J. Abrams (ed.), Encuentro con la sombra. El poder oscuro de la naturaleza humana (Barcelona: Kairós, 2020), 351.

48 Georges-Henri Luquet. El dibujo infantil (Barcelona: Médica y Técnica, 1978), 62. 
y agotamiento de la naturaleza (de la vida espiritual propia) ${ }^{49}$. En este sentido G. Bachelard afirma cómo la imaginación y la memoria conformarían una unidad que se reanudaría en los recuerdos de nuestra «soledad cósmica» donde encontraríamos "el núcleo de infancia que permanece en el centro de la psiquis humana»" diciendo cómo nuestra alma permanecería escondida en el núcleo vivo de nuestra infancia que se haría real mediante la inspiración e iluminación de la poesía, estas ensoñaciones nos ayudarían a descender profundamente, ya que el niño que fuimos «el hijo del cosmos» conocería una felicidad de soñar que en la edad adulta se traduciría en la dicha del poeta: «Mientras sońaba en su soledad el niño conocía una existencia sin límites. Su ensoñación no es simplemente una ensoñación de huida. Es una ensoñación de expansión " ${ }^{51}$.

\section{LOS ANIMALES HÍBRIDOS Y EL DEVORAMIENTO: EL PEZ COMO SÍMBOLO DEL SÍ-MISMO}

El pez constituiría otra imagen de descenso, además de ser un símbolo del «sí-mismo» ya que sería un contenido inconsciente ${ }^{52}$, representando en este sentido «un ser psíquico, en "movimiento penetrante" dotado de poder ascensional en lo inferior, es decir, lo inconsciente ${ }^{53}$. Aparece esculpido en las bases de los monumentos Khmers significando de esta manera cómo estas construcciones «se sumergen en las aguas inferiores, en el mundo subterráneo $»^{54}$. El pez constituiría el animal encajado por excelencia ya que sería «el símbolo del continente redoblando, del continente contenido ${ }^{55}$ que tendría que ver con "un carácter involutivo e intimista de la deglución, mientras que la serpiente se presta más al simbolismo del ciclo " ${ }^{56}$. Pez y serpiente serían al mismo tiempo atributos simbólicos de Cristo y del diablo. La serpiente personifica por norma lo inconsciente, sería un ser ctónico pero también espiritual, mientras que el pez significaría uno de sus contenidos, en el cristianismo es representado innumerables veces como vemos en uno de los canecillos pertenecientes al edificio románico de Nuestra Señora de las Fuentes de Amusco del siglo XIII (fig. 5).

El pez personificaría a Cristo que sería al mismo tiempo el Gran Pescador y el pez. G. Durand señala cómo sería en el doble sentido activo-pasivo del verbo donde habría «que buscar las huellas del mecanismo semántico que ordena tanto la doble negación como la inversión del valor. De este sincretismo de lo activo y de

49 Juan Cirlot. Diccionario..., op. cit., 230.

50 Gaston Bachelard. La poética de la ensoñación (Ciudad de México: Fondo de Cultura Económica, 2019), 164.

${ }^{51}$ Ibidem, 151.

${ }^{52}$ Carl Gustav Jung, AION. Contribución..., op. cit., 153.

53 Juan Cirlot. Diccionario..., op. cit., 372.

${ }^{4}$ Jean Chevalier y Alain Gheerbrant. Diccionario..., op. cit., 823.

55 Gilbert Durand. Las estructuras..., op. cit., 204.

56 Ibidem, 205. 


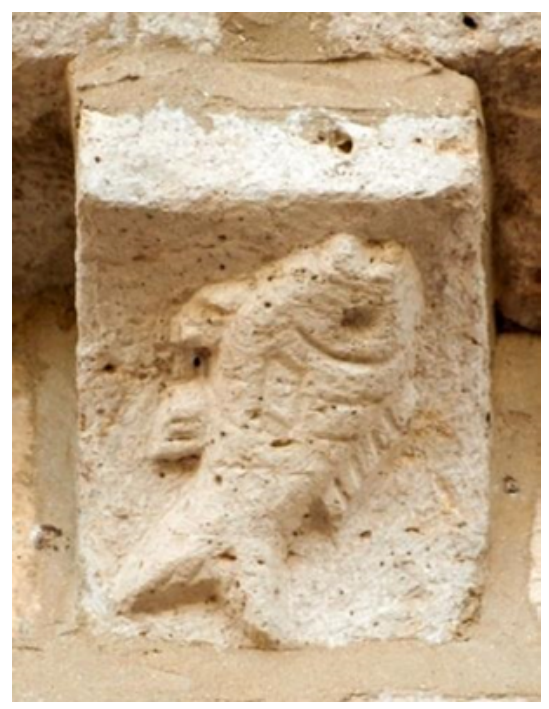

Figura 5. Canecillo de Nuestra Señora de las Fuentes, Amusco (Palencia), siglo xiII.

lo pasivo puede inducirse una vez más que el sentido del verbo importa más a la representación que la atribución de la acción a tal o cual sujeto "' ${ }^{57}$. Así el pez representaría el "esquema del tragador tragado" " ${ }^{58}$, habiendo una relación entre el vientre sexual y el vientre digestivo como vemos en el mito de Isis donde el pez oxirrinco despedazado por Tifon «se traga el catorceavo trozo, el falo, del cuerpo de Osiris»" ${ }^{59}$. Esta deglución del pez pequeño por el grande es dibujada por los niños desde edades muy tempranas (fig. 6).

Las imágenes simbólicas de animales se relacionarían con nuestras fuerzas instintivas del inconsciente, que deben mantenerse en la unidad, esta integración de los instintos constituye una premisa para la individuación. El pez representaría la rehabilitación de nuestros instintos primordiales cuando aparecen figuras compuestas mitad pez y «la mitad de otro animal o de un ser humano. En numerosas mitologías, la diosa luna tiene a menudo una cola de pez» ${ }^{60}$. René Magritte invierte este sentido en su obra La invención colectiva de 1935, donde pinta un pez varado en la playa cuya cola se ha convertido en las piernas de una mujer.

Ya en los comienzos del arte se empezaron a crear seres híbridos como una serpiente gigantesca con cabeza de carnívoro pintada sobre una roca con arcilla de

\footnotetext{
57 Ibidem, 108.

58 Ibidem, 205.

59 Ibidem.

${ }^{60}$ Ibidem, 205
} 


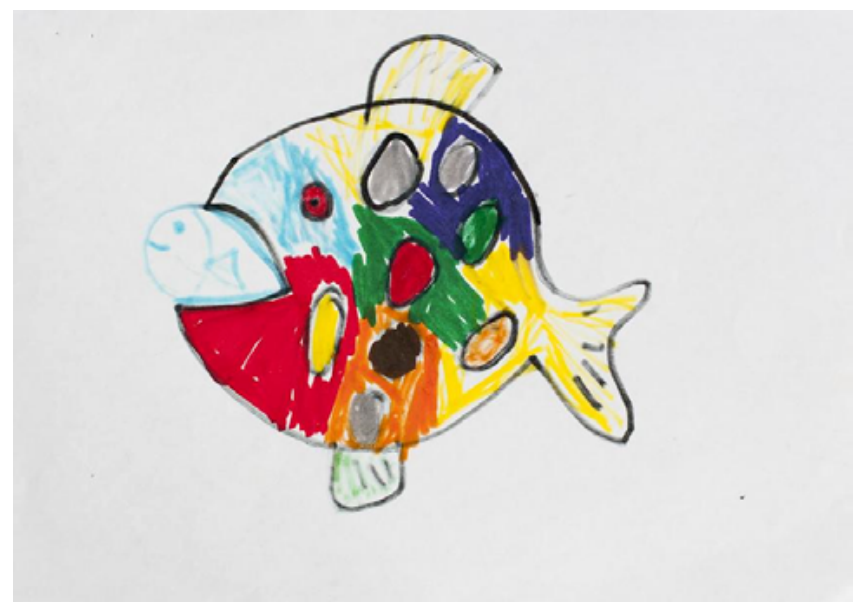

Figura 6. Dibujo de niño de 5 años.

color o un animal compuesto aurińaciense de Le Combel, en Pech-Merle formado por una leona, tres gacelas y un rinoceronte. Otro animal compuesto solutrense encontrado en Le Roc de Serg (Charente) estaría realizado con una mezcla de bisonte con cabeza de cerdo, para S. Giedion la invención de estos «seres inexistentes en la naturaleza responde a un deseo de contacto con potencias imprevisibles» ${ }^{61}$. Los artistas del siglo xx se han inspirado en esta temática multitud de veces, como vemos en Max Ernst, que nos representa estas fusiones en su obra titulada Figura humana de 1931 o El ángel de hogar de 1937. La escultora Daisy Youngblood, seguidora de las teorías de Jung y el budismo, afirma cómo quiere relacionar en su obra el esoterismo y la religión con la psique individual, su obra presenta animales fantásticos como vemos en sus esculturas tituladas Ted Goat de 1983 y Romana realizada en 1987. Según C.G. Jung cuando despiertan los arquetipos se abrirían las puertas a «un mundo espiritual interno del que no sabíamos nada, apareciendo contenidos que tal vez estén en contradicción directa con nuestras viejas opiniones» ${ }^{62}$. Nuestra libido después de liberarse de la «modalidad infantil-personal de la transferencia» bajaría:

... por la pendiente a las profundidades de lo inconsciente, activando allí lo que hasta ese momento yacía adormecido. Ha descubierto el tesoro escondido al que la humanidad ha venido recurriendo desde siempre en sus creaciones y de donde

${ }^{61}$ Sigfried Giedion. El presente..., 549.

${ }^{62}$ Jung Carl Gustav. Escritos..., op. cit., 43. 


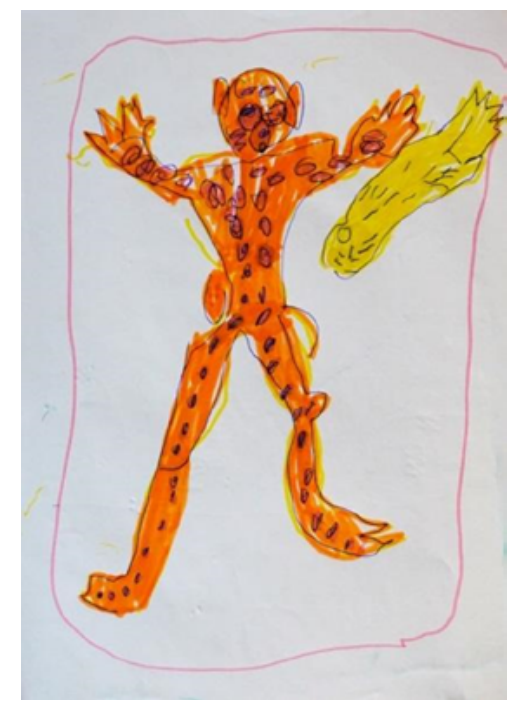

Figura 7. Dibujo de niño de 5 años.

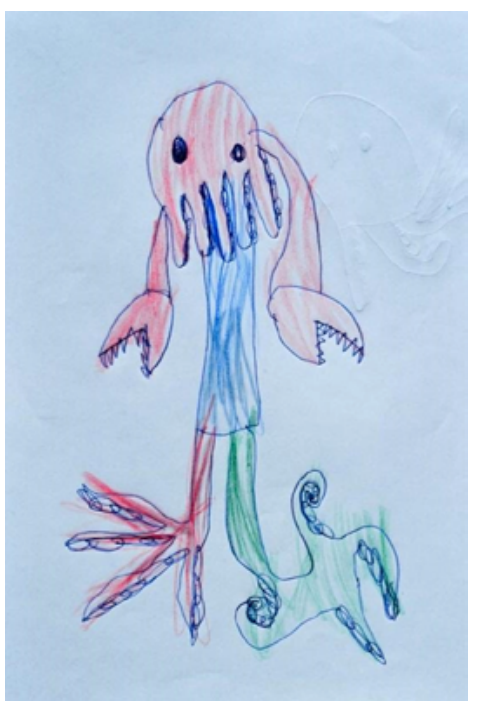

Figura 8. Dibujo de niño de 6 años.

ha hecho que se alzaran sus dioses y demonios y todas esas poderosísimas ideas sin las que el hombre deja absolutamente de ser hombre ${ }^{63}$.

G. Durand afirma cómo los símbolos teriomorfos son de carácter universal, el bestiario estaría «sólidamente instalado tanto en la lengua y en la mentalidad colectiva como en el ensueño individual $\aleph^{64}$, como se puede apreciar en el arte infantil donde aparecen multitud de seres compuestos y relaciones híbridas que nos retrotraerían a estas etapas primitivas de la humanidad (figs. 7 y 8 ).

El bestiario románico, cuyo origen vendría del mundo grecorromano y árabe, sería un bello ejemplo en la representación de seres fantásticos como podemos ver en la Iglesia de San Martín de Frómista (Palencia). El edificio que comenzó a construirse en el año 1066 presentaría bajo los aleros trescientos trece canecillos donde aparecen tallados monjes, cabezas humanas, máscaras, condenados, vicios, virtudes y demonios, predominando la imagen del arquetipo del devoramiento mediante personajes que son tragados o vomitados por el monstruo (figs. 9 y 10).

El devoramiento se asociaría a un nuevo engendramiento o renacimiento que surge de este acto transformador como ocurre en el mito de Jonás y la ballena, donde el protagonista entraría en el vientre del monstruo generalmente marino para

\footnotetext{
63 Ibidem, 32

64 Gilbert Durand. Las estructuras..., op. cit., 205.
} 

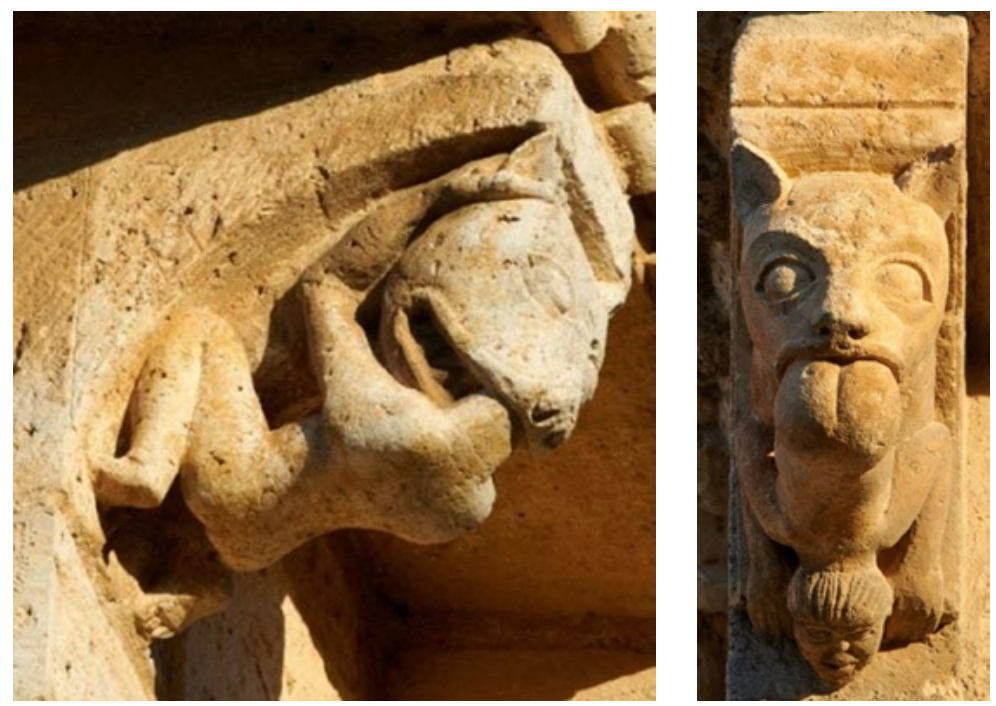

Figuras 9 y 10. Canecillos de la Iglesia de San Martín de Frómista (Palencia).

salir posteriormente de esas tinieblas, constituyendo un rito de iniciación, siendo a menudo un descenso a los infiernos seguido de una resurrección:

El Jonás es eufemización de la deglución, luego antífrasis del contenido simbólico de la deglución. Transfigura el desgarramiento de la voracidad dentaria en un dulce e inofensivo sucking, como Cristo resucitado transformaba al irrevocable y cruel barquero en benéfico protector de un viaje de placer $^{65}$.

Para J. Cirlot, esta iconografía románica donde habría una gran cantidad "de monstruos que tragan o vomitan, o tienen en su interior otros animales, reales o fabulosos, aún enteros no digeridos» significaría de manera correlativa y contraria a la creencia antropófaga de que la víctima devorada «y digiriendo los órganos vitales de su enemigo, acaba de vencerlo, asimilarlo e incorporar sus elementos potenciales» ${ }^{66}$. En este sentido G. Bachelard distinguirá entre el estadio original de la deglución del estado secundario de la masticación, poniendo de ejemplo la ballena de Jonás y el Ogro de Pulgarcito, mientras que la primera víctima engullida por la ballena no causa terror y el personaje tragado no es dañado, el segundo personaje devorado por el Ogro corre una suerte distinta: «La deglución no deteriora, incluso,

65 Ibidem, 196.

66 Juan Cirlot. Diccionario..., op. cit., 179. 


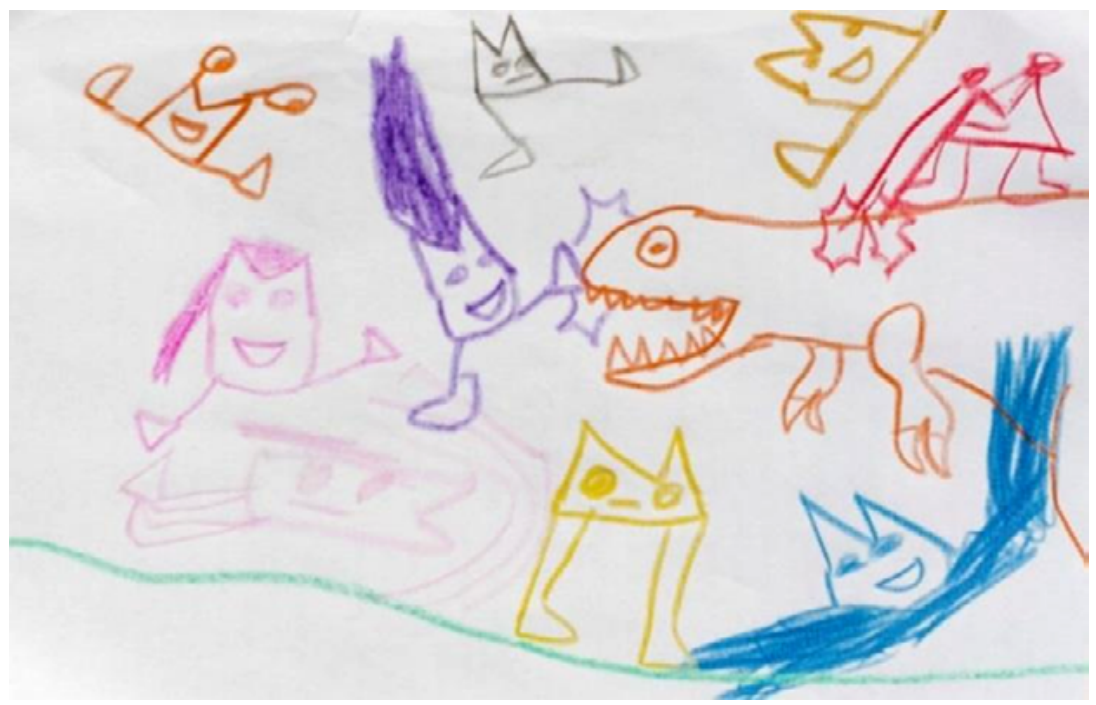

Figura 11. Dibujo de niño de 6 años.

con mucha frecuencia, valoriza o sacraliza ${ }^{67}$. En los niños estudiados podemos ver cómo representarían este arquetipo de totalidad mediante imágenes actualizadas de nuestra época (fig. 11).

Como vemos el mito de Jonás y la ballena tiene que ver con la simbólica del dragón, monstruo que engulle y vuelve a escupir a su presa después de haberla transfigurado. Para C.G. Jung, esta imagen significaría el triunfo del yo sobre las tendencias regresivas, es decir, el lado tenebroso y negativo de la personalidad que permanece inconsciente. J. Campbell señala cómo en todas las culturas aparecen mitos relacionados con el descenso al interior del monstruo, traspasar este umbral implicaría «algún tipo de muerte del yo» ${ }^{68}$. El símbolo universal del vientre de la ballena se convertiría así en "tránsito a través de un umbral mágico en el que el héroe, en lugar de conquistar o reconciliarse con el poder del umbral, es engullido por lo desconocido y parece morir para terminar renaciendo posteriormente» ${ }^{69}$. El viaje del héroe dentro de la ballena y la entrada en el templo equivaldrían a una «expresión alegórica de un proceso de centramiento y renovación de la vida ${ }^{70}$. Este símbolo aparece también en la mitología de la Polinesia, África y Laponia. Artistas como

${ }^{67}$ Gilbert Durand. Las estructuras..., op. cit., 196.

${ }^{68}$ Joseph Cambell. «El vientre..., op. cit., 350.

69 Ibidem, 349.

70 Ibidem, 351. 
Dalí lo representarán en obras como Canibalismo de los objetos-Cabeza de mujer con zapato de 1937. La figura del liliputiense como el de Pulgarcito enlazarían con la doctrina paracelsiana del homúnculo que G. Durand relaciona con la fantasía de la deglución: «El isomorfismo de la gruta, de la concha, del huevo y del Pulgarcito se manifiesta en la imaginación del niño que juega bajo una mesa cubierta por un paño "a la gruta", o a "Patufet", héroe legendario de Cataluña que era "tan pequeño que un día, perdido en el campo, fue tragado por un buey que quería protegerle»"

E. Estrada llama la atención como el juego simbólico tendría su máximo exponente entre los 2-3 y 5-6 años traduciéndose en las manifestaciones plásticas infantiles, ya que el niño interactuaría con los materiales que emplea prestando su voz a los personajes de sus dibujos, además de imitar con estas figuras humanas «las evoluciones y comportamiento sonoro de los variados objetos que ha hecho aparecer sobre la lámina $»^{72}$. En este sentido J. Piaget dice cómo el niño tendría distintas formas de pensamiento representativo donde entraría no solo la representación cognoscitiva sino también la imitación y el juego simbólico que irían evolucionando a la par, destacando cómo el pensamiento del niño sería más simbólico que el del adulto debido a que el niño sería capaz de interiorizar sus representaciones. La función simbólica sería para Piaget una conexión que se produciría en el niño entre significantes y significados y donde la representación surgiría de la unión de significantes que permitirían al niño «evocar los objetos ausentes por medio de un juego de significaciones que los relaciona con los elementos presentes ${ }^{73}$. El niño cuando se relaciona con el objeto haría una imagen que sería una "imitación interiorizada del objeto» ${ }^{74}$ y que puede reproducir de manera plástica mediante el dibujo o el volumen, siendo esta función de un carácter eminentemente lúdico y que se produciría igualmente en el pensamiento del artista adulto siendo en muchos casos de carácter inconsciente como se puede comprobar en estas imágenes de los dedos de la mano simbolizados tanto de manera gráfica como de bulto redondo con técnicas como el modelado en barro pertenecientes a dos niños de ocho años (figs. 12 y 13).

Pulgarcito representaría "la conciencia absoluta, clarividente, enérgica y activa, que dirige la vida entera y la conduce a la salvación ${ }^{75}$, a nivel general simbolizaría el principio salvador de la sociedad, siendo también el «símbolo del principio director de la persona, que está repartido entre diversos elementos, como la sociedad entre diversos miembros ${ }^{76}$. Según J.E. Cirlot los enanos al igual que los dáctilos, gnomos y duendes, serían una personificación de los poderes que estarían fuera del campo de la consciencia, este autor siguiendo a Jung dice cómo «en el plano psico-

${ }^{71}$ Gilbert Durand. Las estructuras..., op. cit., 201.

${ }^{72}$ Eugenio Estrada Diez. Génesis y evolución del lenguaje plástico de los niños (Zaragoza: Mira Editores, 1991), 31.

${ }^{73}$ Jean Piaget. La formación del simbolo en el niño, imitación, juego y sueño, imagen y representación, (Ciudad de México: Fondo de Cultura Económica, 2019), 379.

${ }^{74}$ Ibidem, 383.

${ }^{75}$ Jean Chevalier y Alain Gheerbrant. Diccionario..., op. cit., 859.

76 Ibidem, 858-859. 


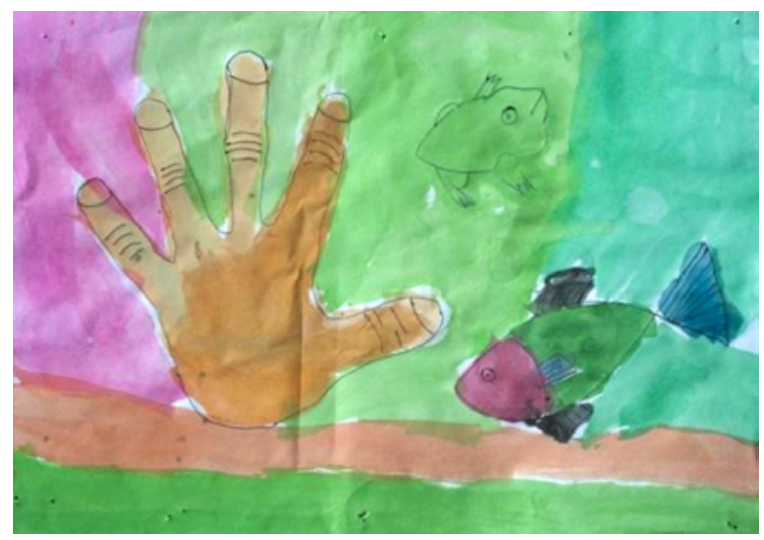

Figura 12. Dibujo de un niño de 8 años.

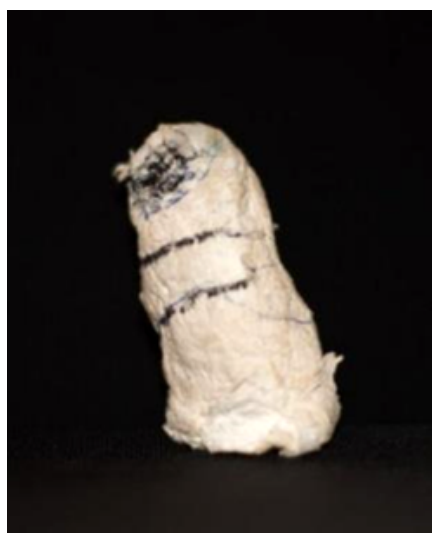

Figura 13. Representación de un dedo de nińo de 8 años.

Papel pintado.

lógico pueden considerarse como guardianes del umbral del inconsciente» ${ }^{77}$. Dalí representará este tipo de seres mediante un racimo de dedos pulgares que parecen tener vida propia surgiendo de una copa en su obra titulada Aparición de un rostro y un frutero en la playa de 1938.

Según Piaget el problema del nacimiento en el pensamiento de los nińos tendría relación con un artificialismo donde encontramos «una evolución de los mitos relativos al origen del hombre, en el sentido de un artificialismo cada vez más inmanente, es decir, atribuido a la misma naturaleza ${ }^{78}$. Sobre el origen del ser humano sobre la tierra los niños creen que el hombre desciende de las plantas habiendo concomitancias con los cuentos populares como Pulgarcita o las más antiguas representaciones de seres humanos que surgen de árboles, flores o vegetales como vemos en un silbato maya de cerámica de 550-850 de la isla de Jaina donde germinaría de una flor la efigie de Xochiquétzal o «flor pluma» diosa del amor y la transformación espiritual. Para G. Durand estos símbolos realizarían una inversión que nos haría comprender el reverso de las cosas existiendo un proceso simbólico de minimización que iría desde la nave al cuévano llevándonos a «los pequeños recipientes, cuyos prototipos naturales son la cáscara, la concha, el grano, la yema floral o el cáliz vegetal mientras que el cofre y sobre todo la copa son los fiadores técnicos» ${ }^{79}$.

Los artistas adultos al igual que los niños serían capaces de conectar a través de sus fantasías creadoras con residuos de nuestro pasado evolutivo pero también con nuestra realidad cósmica universal como afirma el antropólogo L. Duch que

77 Juan Cirlot. Diccionario..., op. cit., 193.

78 Jean Piaget. La representación..., op. cit., 311.

79 Gilbert Durand. Las estructuras..., op. cit., 240. 
llama la atención de cómo en el ser humano habría una potenciación de lo cósmico y lo onírico que daría lugar a una poética: «Lo simbólico proclama que la búsqueda constante del "paraíso perdido" es una empresa humana, y que solamente en esta incesante búsqueda se manifiesta plenamente la humanidad del hombre en su pluridimensionalidad y en su fuerza creadora $»^{80}$.

\section{LA TRANSFORMACIÓN DE LA CONSCIENCIA Y EL ARTE}

J. Matthews señala cómo los primeros trazos que el niño dibujaría espontáneamente estarían impregnados «de profundos significados expresivos y representacionales ${ }^{81}$, haciendo una comparación entre los dibujos infantiles y los del artista adulto lo que le lleva a concluir cómo el dibujo infantil y sus primeras representaciones tendrían como objetivo una búsqueda de la identidad como lo haría un creador plástico además de una búsqueda «de las identidades y estructuras de eventos y objetos ${ }^{82}$. Como vemos los niños tendrían un lenguaje artístico propio generador de símbolos capaz de conectar con otras zonas de su psique por lo que en nuestra educación artística infantil sería interesante crear un ambiente que estimule la creatividad respetando en todo momento su imaginación y espontaneidad para que sus emociones no sean reprimidas y puedan así abrirse nuevos caminos que potencien la consciencia de los niños. Para M.C. Debienne la educación infantil en relación con el arte debería evitar el fomento de las técnicas descriptivas como la copia del natural para así preservarse en el niño su tendencia personal para expresarse gráficamente y poder así seguir «expandiéndose como fuente de júbilo, en la adolescencia", nombrando a autores como Stern que creen cómo habría que proteger y cultivar este lenguaje plástico del niño que sería un lenguaje artístico producido mediante imágenes que cubriría «una zona de la vida interior distinta a la correspondiente a las ideas de que se nutren las palabras» ${ }^{83}$.

L. Duch señala como el ser humano tendría un potencial no solo de transformación, sino también de recreación e interpretación gracias a su capacidad simbólica, esto propiciaría que nuestra libertad pueda "tomar cuerpo en este mundo» ${ }^{84}$. Henry Corbin define la imaginación como la «memoria deseante», insatisfecha con un presente no solo meramente fáctico, sino también bien determinado, que no tendría poder de transfiguración de nuestro presente. En su obra Avicena y el relato visionario escribe: «... la visión simbólica implica la transmutación concomitante del

${ }^{80}$ Luis Duch. Antropología de la vida cotidiana. Simbolismo y salud (Madrid: Trota, 2003), $38-39$.

81 John Matthews. El arte de la infancia y la adolescencia. La construcción del significado. Col. Arte y educación n. ${ }^{\circ} 2$ (Barcelona: Paidós, 2002), 33.

82 Ibidem, 63.

${ }^{83}$ Marie-Claire Debienne. El dibujo en el niño. Col. Paideia. Biblioteca práctica de pedagogía, psicología y psicopatología de la infancia n. ${ }^{\circ} 49$ (Barcelona: Planeta, 1979), 129.

${ }^{84}$ Luis Duch. Antropología..., op. cit., 39. 
modo de percepción y del modo de ser del perceptor y de lo percibido, lo que postula la espontaneidad de la Imaginación, que es el órgano de estas metamorfosis» ${ }^{85}$. Joan-Carles Mèlich escribe en su obra Antropología simbólica y acción educativa de 1996, como el mundo de la vida sería simbólico, mítico y ritual. Siendo a partir de lo simbólico, de la poesía, del teatro, del mito y del ritual, como «las antinomias de la razón vislumbran la claridad $»^{86}$.

Para C.G. Jung la nueva psicología tendría un carácter educativo ya que en cada ser humano habría "una combinación nueva y única de elementos psíquicos» ${ }^{87}$, señalando como nuestro pasado incidiría sobre nosotros, pero también estaríamos determinados por nuestro futuro, que «con mucha antelación ya está depositado en nosotros. Esto sucede muy especialmente en una persona creativa, que no conoce sus numerosas posibilidades, aunque todas están listas en ella ${ }^{88}$. Autores como M. Pérez Bautista afirman cómo poseeríamos una consciencia en desarrollo, encontrándonos en plena evolución como podemos comprobar mediante el funcionamiento cerebral, que tendría un grandioso entramado de interconexiones sinápticas entre las neuronas, ya que contendría 100000 millones, a lo que habría que añadir la multitud de conexiones sinápticas que pueden darse entre ellas, calculándose un promedio 10000 por cada neurona. Por lo que este autor concluye que «es razonable dudar de que todo eso esté ya operando adecuadamente y al máximo de sus posibilidades» ${ }^{89}$. El ser humano poseería facultades que no estarían funcionando, pero que en un futuro se podrían activar, si de produjeran «los desarrollos complementarios pertinentes», por lo que deduce que "dispondríamos de un potencial de desarrollo insospechado», que podría dar "pie a nuevas transformaciones en nuestra especie $»^{90}$, para este autor la imaginación puede cambiar nuestra anatomía cerebral, induciendo y potenciando una cierta reorganización del funcionamiento del cerebro y de su fisiología.

En este sentido K. Korotkov cree que el ser humano tendría "cualidades especiales» si las comparamos con el mundo animal, afirmando cómo el desarrollo centrífugo que estamos viviendo en nuestra civilización tendría que ver con el aumento global de «la consciencia colectiva de la humanidad, que despliega su poder potencial en el espacio y el tiempo de nuestro universo ${ }^{91}$. Según este científico un alto nivel de consciencia sería capaz de generar nuevas ideas que no estarían basadas en el actual conocimiento y desarrollo social, por lo que tendrían la capacidad de

1979), 122.

${ }^{85}$ Ibidem, citando a Henry Corbin, Avicena y relato visionario (Barcelona: Paidós Ibérica,

${ }^{86}$ Ibidem, 247.

${ }^{87}$ Carl Gustav Jung. Sobre el desarrollo de la personalidad, vol. 17 (Madrid: Trotta, 2016), 91.

${ }^{88}$ Ibidem, 105.

${ }^{89}$ Manuel Bautista Pérez. La paradoja de Darwin o el enigma del Homo sapiens. Col. Divulgación Científica (Córdoba: Guadalmazán, 2015), 408.

${ }_{90}$ Ibidem, 410.

${ }^{91}$ Konstantin Korotkov. La energía de la consciencia. (Barcelona: Ediciones Obelisco, 2015), 165 . 
transformar la sociedad. La creatividad jugaría un importante papel en este proceso ya que constituiría la base donde desarrollaríamos nuevas ideas que potenciarían el avance de la civilización para llegar al siguiente nivel: «Presumiblemente, lo hacen mediante la conexión al Campo Informativo Universal y recibiendo información directa de los Planos Superiores de la Consciencia» ${ }^{92}$.

Según Sri Aurobindo, a través de la supermente el ser humano viviría en lo esencial y no en lo fenoménico, en lo que denomina «el yo» viendo todo como el ser del yo, de manera que su poder, forma, movimiento, todo el pensamiento y sus procesos tendrían este carácter de la supermente que sería capaz de invertir el orden total de nuestro pensamiento mental. Es a través de la intuición, poder de la consciencia más cercano al conocimiento original como podemos rememorar la verdad que se encuentra oculta y así abrir paso en el ser humano a una consciencia más grande:

Esta percepción profunda es más que una visión, más que una concepción; es el resultado de un toque penetrante y revelador que trae consigo la visión y la concepción como parte de sí mismo o como su consecuencia natural. Una identidad escondida o adormecida, que todavía no se ha reencontrado así misma, recuerda sin embargo y transmite a través de la intuición su propio contenido y la intimidad de su sentimiento y de su visión espontánea de las cosas, la luz de su verdad, su certidumbre irresistible y automática ${ }^{93}$.

Para este autor el motivo principal de nuestra evolución sería la emergencia y crecimiento de la consciencia, este crecimiento no solo consistiría en una ampliación de nuestras capacidades, sino también en nuestro ascenso a niveles superiores hasta alcanzar el más elevado posible:

Pues la evolución parte del nivel más bajo de involución en el Inconsciente donde la vemos trabajar en el seno de la Materia creando el universo material; opera en la Ignorancia que, sin embargo, lleva en sí un conocimiento que se va desarrollando constantemente y del que surge una luz cada vez mayor, una organización y una voluntad efectiva siempre mayores, y una armonización de sus propios poderes inherentes a medida que emergen ${ }^{94}$.

La poesía y el arte deben ser elevados de manera que las posibilidades que alcancemos e incluso cualquier perfección ya conseguida tenemos que integrarla «en una perfección nueva y superior con una visión e inspiración más amplia de una consciencia espiritual y con nuevas formas y poderes» ${ }^{95}$. El ser humano no sería un individuo que existiría en solitario, siendo lo universal su base y su matriz actual,

92 Ibidem, 152.

${ }^{93}$ Sri Aurobindo. La evolución futura del hombre (Barcelona: Fundación Centro Sri Aurobindo, 1999), 130.

94 Sri Aurobindo. La manifestación supramental sobre la tierra (Barcelona: Fundación Centro Sri Aurobindo, 2004), 28.

${ }_{95}$ Ibidem, 19. 
pues como dice Sri Aurobindo el hombre sería en su ser fenoménico un resultado de lo universal. El individuo verdadero no es el ego, «sino la individualidad divina que, a través de nuestra evolución, se dispone a emerger en nosotros» ${ }^{96}$, diciendo cómo el yo secreto estaría en nuestro interior y sería un yo intuitivo que se aposentaría «en el centro de nuestro ser, el físico, el nervioso, el emocional, el volitivo, el conceptual o cognitivo y el centro superior más directamente espiritual». Este yo ejercería en cada parte de nuestro ser «una secreta iniciación intuitiva de nuestras actividades, que es recibida y representada imperfectamente por nuestra mente externa y convertida (dentro de los movimientos de la ignorancia) en la acción externa de estas partes de nuestra naturaleza ${ }^{97}$. El ser estético buscador de belleza iría sin saberlo detrás del Absoluto, en este proceso su parte infrarracional se dirigiría hacia el Divino de forma ciega, siguiendo sus instintos, necesidades e impulsos, su parte racional perseguiría y analizaría sus diferencias, analizándolas e imponiendo su lógica y su orden, mientras que su parte suprarracional se situaría «detrás de las cosas, por encima de las cosas y en las partes más recónditas de su ser, para tocar y captar la Realidad misma en su corazón y su esencia, e iluminar todos los infinitos detalles de ese centro secreto" ${ }^{98}$.

En nuestra educación es importante el respeto al desarrollo de la consciencia del niño, además de proporcionarle los instrumentos necesarios para que pueda potenciar su propia experiencia subjetiva y personal en los procesos artísticos. Para ello tendríamos que analizar qué es el ser humano, acercándonos a su psicología y fomentando una educación artística donde prime la libertad que rompa definitivamente con una actitud disociativa instaurada en la educación que estaría induciendo y condicionando la experiencia sensitiva y sensorial en el desarrollo progresivo de la consciencia del niño. E. Pérez de Carrera afirma que para llevar a cabo este camino de aventura tendríamos que dejar a un lado nuestra razón y romper con la disociación donde el pensamiento se comportaría de manera lineal y cronológica, ya que esta circunstancia estaría en contra de nuestro funcionamiento biológico que no sería cronológico como podemos comprobar en nuestra vida y en nuestras sensaciones, señalando cómo cada ser humano tendría «su propio idioma, porque cada significación vive en un ideograma distinto y toda palabra desarrolla el dibujo de un pictograma único en cada cerebro" "99. Para E. Pérez de Carrera el nuevo paradigma que ha de nacer estaría cercano a una configuración que rompa con los estereotipos y se acerque a un concepto máximo del ser humano, que sería el arte relacionado con todo y que todos podemos ser artistas. Este autor reflexiona sobre la transmisión de valores trascendentes en el sistema educativo actual, basándose en el amor como vehículo fundamental para su consumación, definiendo la vida creativa como una actitud: «Vivir creativamente es encender los sentidos por dentro y por fuera,

\footnotetext{
1980), 187-188.

${ }_{98}$ Sri Aurobindo. El ciclo..., op. cit., 172.

99 Eduardo Pérez de Carrera. 49 respuestas a la aventura del pensamiento. Tomo I (Madrid: Fundación Argos, 2004), 44.
}

96 Sri Aurobindo. El ciclo humano (Barcelona: Fundación Centro Sri Aurobindo, 2002), 66.

${ }_{97}$ Sri Aurobindo. Sintesis del Yoga, libro. III, Yoga de Autoperfección (Buenos Aires: Kier, 
es no esconderse ante el ojo que te mira y no disfrazar la mirada hacia el iris que busca un espejo» ${ }^{100}$.

\section{CONCLUSIONES}

El arte infantil a través de la fantasía creadora sacaría a la luz del inconsciente una importantísima riqueza de imágenes simbólicas relacionadas con el descenso que suelen ir constantemente acompañadas por símbolos de intimidad como protectores en este viaje al interior de nuestro yo más secreto. Muchas de ellas relacionadas con esquemas geométricos como el cuadrado, el rectángulo, el triángulo y el círculo que representarían en muchas ocasiones el centro psíquico del niño como es el caso de la ciudad, la fortaleza o la ciudadela. Arquetipos con una geometría cerrada cuadrada y rectangular que tendrían que ver con una defensa de nuestra integridad interior. Mientras que el círculo o la esfera representarían un centro perfecto una imagen de intimidad espacio sagrado que enlazaría con el Paraíso y que en el arte infantil aparecería a edades muy tempranas mediante imágenes circulares en forma de sol, mandalas y símbolos concéntricos con una serie de anillos que partirían de un centro.

Otras imágenes del centro serían el cofre y la caverna relacionadas con el simbolismo del corazón, este último enlazaría con el vaso y el cáliz y el triángulo invertido que designaría la Madre al igual que la cavidad, el útero, las entrañas, la cámara, la copa, el grial, el vaso, el recipiente o la caverna, lugar donde se produciría una revitalización como ocurre en el interior del templo cristiano, en el sepulcrocatacumba y en la casa-relicario que los niños representarían mediante un «modelo interno".

El pez sería otra imagen de descenso siendo un símbolo del «sí-mismo» un ser psíquico capaz de ascender desde el inconsciente, teniendo un significado involutivo relacionado con la deglución que los niños dibujarían gráficamente mediante el pez pequeño tragado por el grande. Las imágenes simbólicas de animales se relacionarían con nuestras fuerzas instintivas del inconsciente que nos pondrían en contacto con partes desconocidas de nuestro ser. Al igual que ocurre con el arquetipo del devoramiento que aparece en el relato de Jonás y la ballena y el Ogro de Pulgarcito donde los personajes son tragados o vomitados por el monstruo en un acto de valorización o sacralización de la víctima; arquetipos representados en el arte infantil mediante imágenes actualizadas a nuestra época. En este proceso simbólico de minimización donde se produce una inversión encontramos las figuras del homúnculo, los enanos, los dáctilos, los gnomos y duendes personificaciones de los poderes que estarían fuera del campo de la consciencia, siendo los guardianes de la frontera de nuestro inconsciente. Estos personajes minúsculos en muchos casos son interpretados plásticamente por los niños que creerían que el hombre desciende de las plan-

100 Ibidem, 14. 
tas habiendo concomitancias con los cuentos populares como Pulgarcita o las más antiguas representaciones de seres humanos que surgen de árboles, flores o vegetales.

Estas figuras mitológicas nos ayudarían a descubrir otras partes de nuestra psique donde operarían unas determinadas teologías, lo que demostraría que estas representaciones artísticas infantiles tendrían concomitancias con las manifestaciones de la actividad espiritual humana estudiadas en la investigación etnológica. De esta manera el arte se convertiría en una fuente importantísima en la aportación de símbolos que tendrían una gran influencia en nuestra vida psíquica, ya que constituirían símbolos de transformación que armonizarían nuestra unidad psíquica interna. En las manifestaciones artísticas de los niños surgirían arquetipos y símbolos de descenso e intimidad creados a partir de su vivencia primordial. El niño al igual que el artista conformaría a través de esta imagen primigenia un lenguaje actualizado donde convocaría aquellas figuras simbólicas de las que carece la consciencia social, volviendo así a abrir «todos los caminos que conducen a las fuentes más profundas de la vida, que de otro modo nos estarían vedadas. Aquí radica la relevancia social del arte: siempre trabaja en la educación del espíritu de la época... ${ }^{101}$.

Aceptado: febrero de 2021; aceptado: noviembre de 2021

${ }^{101}$ Carl Gustav Jung. Sobre el fenómeno..., op. cit., 74. 


\section{REFERENCIAS BIBLIOGRÁFICAS}

Aurobindo, Sri. El ciclo humano. Barcelona: Fundación Centro Sri Aurobindo, 2002.

Aurobindo, Sri. La evolución futura del hombre. Barcelona: Fundación Centro Sri Aurobindo, 1999.

Aurobindo, Sri. La manifestación supramental sobre la tierra. Barcelona: Fundación Centro Sri Aurobindo, 2004.

Aurobindo, Sri. Sintesis del Yoga. Libro. III, Yoga de Autoperfección. Buenos Aires: Kier, 1980.

Bachelard, Gaston. La poética de la ensoñación. Ciudad de México: Fondo de Cultura Económica, 2019.

Bautista Pérez, Manuel. La paradoja de Darwin o el enigma del Homo sapiens. Col. Divulgación Científica. Córdoba: Guadalmazán, 2015.

CAmbell, Joseph. «El vientre de la ballena», en C. Zweig y J. Abrams (ed.), Encuentro con la sombra. El poder oscuro de la naturaleza humana. Barcelona: Kairós, 2020, pp. 349-353.

Chevalier, Jean y Gheerbrant, Alain. Diccionario de los simbolos. Barcelona: Heder, 1999.

Cirlot, Juan. Diccionario de símbolos. Barcelona: Labor, 1969.

Debienne, Marie-Claire. El dibujo en el niño. Col. Paideia. Biblioteca práctica de pedagogía, psicología y psicopatología de la infancia n. ${ }^{\circ}$ 49. Barcelona: Planeta, 1979.

Duch, Luis. Antropología de la vida cotidiana. Simbolismo y salud. Madrid: Trota, 2003.

Durand, Gilbert. Las estructuras antropológicas de lo imaginario. Introducción a la arqueología general. Madrid: Taurus. 1981.

Estrada Diez, Eugenio. Génesis y evolución del lenguaje plástico de los niños. Zaragoza: Mira Editores, 1991.

Giedion, Sigfried. El presente Eterno. Col. Alianza Forma n. ${ }^{\circ}$ 16. Madrid: Alianza, 1991.

JAFFÉ, Aniela. «El simbolismo en las artes visuales», en C.G. Jung (ed), El hombre y sus símbolos. Col. Biblioteca Universal n. ${ }^{\circ}$ 3. Barcelona: Caralt, 1997, pp. 229-275.

Jové, Juan José. El desarrollo de la expresión gráfica. Col. Cuadernos de Educación nº15. Barcelona: Horsori, 1994.

Jung, Carl Gustav, AION. Contribución a los simbolismos del si-mismo. Col. Biblioteca de Psicología Profunda n. ${ }^{\circ}$ 113. Barcelona: Paidós, 1995.

Jung, Carl Gustav. El libro rojo. Buenos Aires: El hilo de Ariadna, 2019.

Jung, Carl Gustav. Escritos sobre espiritualidad y transcendencia. Madrid: Trotta, 2018.

Jung, Carl Gustav. La psicología de la transferencia. Col. Biblioteca Profunda n. ${ }^{\circ}$ 6. Barcelona: Paidós, 1993.

Jung, Carl Gustav. Psicología y simbólica del arquetipo. Col. Biblioteca de Psicología Profunda n. ${ }^{\circ} 29$. Barcelona: Paidós, 1990.

Jung, Carl Gustav. Recuerdos, sueños, pensamientos. Col. Biblioteca Breve, Barcelona: Seix Barral, 1996.

JunG, Carl Gustav. Sobre el desarrollo de la personalidad, vol. 17. Madrid: Trotta, 2016.

Jung, Carl Gustav. Sobre el fenómeno del espiritu en el arte y en la ciencia, vol. 15. Madrid: Trotta, 2007.

JunG, Carl Gustav. Tipos psicológicos. Barcelona: Edhasa, 1994.

Korotrov, Konstantin. La energía de la consciencia. Barcelona: Ediciones Obelisco, 2015. 
Lawlor, Robert, Geometría Sagrada. Madrid: Debate, 1993.

Lowenfeld, Viktor y Lambert, William. Desarrollo de la capacidad intelectual y creativa. Madrid: Síntesis. 2008.

LuQuet, Georges-Henri. El dibujo infantil. Barcelona: Médica y Técnica, 1978.

Machón Durango, Antonio. Los dibujos de los niños. Génesis y naturaleza de la representación gráfica: un estudio evolutivo. Madrid: Cátedra, 2010.

Matthews, John. El arte de la infancia y la adolescencia. La construcción del significado. Col. Arte y educación n. ${ }^{\circ}$ 2, Barcelona: Paidós, 2002.

Pérez de Carrera, Eduardo. 49 respuestas a la aventura del pensamiento, tomo I. Madrid: Fundación Argos, 2004.

Piaget, Jean y Inhelder, Bärbel. Psicología del niño. Madrid: Morata, 2015.

Piaget, Jean. La formación del símbolo en el niño, imitación, juego y sueño, imagen y representación, Ciudad de México: Fondo de Cultura Económica, 2019.

Piaget, Jean. La representación del mundo en el niño, Madrid: Morata, 2008.

Widlöcher, Daniel. Los dibujos de los niños. Bases para una interpretación psicológica. Barcelona: Herder, 1982. 